\title{
FACTORS AFFECTING CEMENT PASTE WHEN USED AS A BINDING AGENT WITH RICE HUSKS
}

\section{OPARA P.N.}

\begin{abstract}
Cement is one of the most widely used binding agent especially in the construction of buildings. The most commonly used type of cement is Portland cement. Portland cement is very effective in concrete works, mortar, block moulding of different types etc. unfortunately cement pest is affected by a number of factors including acids, sulphates etc. The study revealed that cement is affected by calcium chloride, chloride suphate, magnesium and sodium salt. These chemicals attack and destroy the binding power of cement. "If a salt looses its savour, how shall it be salted? It is therefore good for nothing but to be cast out and to be trodden under foot of men" - Mathew 5:13". Also the study revealed that cement retarding sulphate and acid are presented in clay, brick, soil and ground water. To remedy the situation recommendations were made on how to overcome the problems.
\end{abstract}

Key words: cement paste, binding agent, rice husks

\section{INTRODUCTION}

Cement is a mixture of clay and ground lime stone or chalk burnt at a high temperature in a rotary kiln which forms clinker. When the clinker is ground to fine power with a mixture of gypsum Portland cement is formed. When cement is place. During the chemical reactions, every cement particle grows or become larger in size. The growth or enlargement of the particles result in setting, stiffening, hardening and development of strength. Workability is lost as a result of growth on the cement particles. The concrete formed after the setting of cement is strong in compression but weak in tension. Amobi (2005) stressed that the success of concrete structure depends on good design and detailing structure, the use of good quality materials that are clean and free from impurities, the correct measurement of all ingredients which include adequate mixing of ingredient, the correct placing and adequate compaction of concrete, adequate curing of the concrete.

\section{Types Of Cement}

There are many types of cement in existence. The different types of cement are used for different purposes depending on the nature of work to be done. Usually, the type of cement used in any contract is specified by the engineer or architect. George (1975) stated that the types of cement existing in the market are: Ordinary Portland Cement, Portland blast furnace Cement, White Portland Cement, Masonry Cement, Rapid hardening cement, Low-heat Portland cement, Sulphate resistant Portland cement, Water repellent Portland cement, Hydrophobic Portland cement, High Alumina cement, Supersulphate cement. The Local material that can be used in the production of roofing sheets are: Rice husk, Cocoa nut fibre, Saw dust, Palm nut fibre

\section{Factors Effecting Cement Paste When Used With Local Materials}

In a study of chemical attack of sodium chloride on Portland cement paste, Monosi, Alvera and Colepard (1989) revealed that chloride constitute a danger to portland cement and reinforcement embedded in the concrete. This is because chloride promotes rusting. Also Monosi, Alvera and colepard noted that thirty percent of sodium chloride aqueus solution is very aggressive towards Portland cement. According to the researchers it causes swelling and cracking in concrete. The common name for sodium chloride is common salt $\left(\mathrm{Nacl}_{2}\right)$. 
Maslehuddin (1990) in his report on the performance of concrete in a high chloride-sulphate environment revealed that the service condition for concrete construction in coastal areas of the Arabian gulf are considered to be one of the most aggressive environments in the world. The report revealed that the deterioration of cement paste due to salt attack is one of the leading reasons for poor performance of concrete structures. He noted that calcium, magnesium and sodium water and aggregate. Maslehuddin however reiterated that field and labouratory studies are in progress at king Fahd University of petroleum and mineral resources at Dhatran, Saudi Arabia to formulated preventive measures.

George (1980) revealed that sulphates may be present in clay, brick, soil, ground water. Sulphate resisting cement can be used to resist the attack of sulphates. Most importantly, George revealed that the durability of concrete and its resistance to all forms of chemical attack depend primarily on it being dense, impermeable and well compacted.

Also Lewis (1990) in a study presented in Paul Klieger Symposium on the performance of concrete depends on correct choice and use of materials. Lewis stated that problems such as ASR (Alkali - Silica reaction) and the prospect of sulphate attack and corrosion need early and proper identification and attention. also Lewis reiteration that resistant materials must be selected and properly used to ensure control of these adverse condition. Lewis concluded that Low alkali cement or sulphate resisting cement must be used as appropriate to prevent or minimize thermal cracking of massive structural concrete such as power plank, bridge, foundation elements and thick linings of larger tunnels.

Okorie J.U (1988) revealed that oil is processed from bran which is a bi-product of rice milling. This indicates that there are some oily substance in rice husk. Parry (1985) recorded that stiff fibre, oily or greasy to touch, impregnated with cement affecting chemicals, presence of sugar and fibre susceptible to large dimensional changes when changing between wet and dry state affect and destroys the binding power of cement.

The presence of calcium chloride promotes rusting. In cement based products. It causes swelling and cracking. It is very aggressive to cement.

Table 1: Effect of chemicals and oil or greasy substances on cement paste in the production of rice husk roofing sheets

\begin{tabular}{|c|c|c|c|c|}
\hline S/NO & Tests carried out & $\begin{array}{l}\text { Sample. } \\
\text { treated }\end{array}$ & $\begin{array}{l}\text { Sample B } \\
\text { Not treated }\end{array}$ & Remarks \\
\hline 1 & General observation & Ash or grey & Dark grey & $\begin{array}{l}\text { A (treated) is } \\
\text { better than B (not } \\
\text { treat) }\end{array}$ \\
\hline 2 & Surface defects & $\begin{array}{l}\text { No visible } \\
\text { crack }\end{array}$ & $\begin{array}{l}\text { Visible cracks and } \\
\text { blisters }\end{array}$ & $\begin{array}{l}\text { B (Not good at } \\
\text { all) }\end{array}$ \\
\hline 3 & Texture & $\begin{array}{l}\text { Slightly } \\
\text { smooth }\end{array}$ & Very rough & $\begin{array}{l}\text { B (Not good at } \\
\text { all) }\end{array}$ \\
\hline 4 & Density & $\begin{aligned} & 4.9475 \\
& 0.00270 \\
= & 1832.44\end{aligned}$ & $\begin{array}{l}\text { Could not be determine } \\
\text { because it was almost in } \\
\text { peaces }\end{array}$ & $\begin{array}{l}\text { B (Nothing to } \\
\text { write home about) }\end{array}$ \\
\hline 5 & Water permeability & Impervious & Very porous & B (not good at all) \\
\hline
\end{tabular}




\begin{tabular}{|l|l|l|l|l|}
\hline 6 & $\begin{array}{l}\text { Water absorption } \\
\text { after 24 hrs (\%) } \\
\text { Breaking load } \\
(\mathrm{kg} / \mathrm{mm})\end{array}$ & 13.42 & Could not be determined & B (not good at all) \\
8 & $\begin{array}{l}\text { Fire resistance } \\
\text { Broke in pieces. Could } \\
\text { not be determine }\end{array}$ & B (not good at all) \\
\hline
\end{tabular}

Sample A was treated with Alum and washed thoroughly. This reduced the attack of acids, sulphate and oily substances hence a fairly good and stable roofing sheets was produced. Sample B was not treated hence the attack of acids, sulphate and oily substances made its product very poor and not acceptable.

\section{RECOMMENDATIONS}

Cement retarding chemical can be removed or separated from a material used for construction or manufacturing of cement based roofing sheet by washing and drying, and boiling. Parry (1985) reported that in addition to separation, washing and drying fibre for cement-fibre concrete should be boiled to remove cement retarding chemicals. Maslehudeen (1990) noted that if the materials are not well washed and dried it could result in the swelling of the concrete and formation of cracks. When the cement retarding chemical are removed the cement will work effectively.

The presence of oily and greasy substances including sugar can retard the binding power of cement and render it ineffective. This can be remedied by boiling the substance or by washing it with a solution of Alum. Alum is colourless soluble hydrated double sulphate of aluminum and potassium used in manufacturing and in medicine with formula $\mathrm{K}_{2} \mathrm{So}_{4} . \mathrm{AI}_{2}\left(\mathrm{So}_{4}\right) \mathrm{s}$. in $24 \mathrm{H}_{2} \mathrm{O}$.

To exterminate cement retarding organisms in a material used for production of roofing sheets, the material could converted from organic to inorganic material by burning. When rice husk is burnt it changes into ashes. Rice husk ash is a pozzolana material. Pozzolana materials are not cementitious materials. They are in finely divided forms. In the presence of water, they react with lime to produce compounds with cementitious properties. Onyemachi (1994) in a study of the utility of rice husk and its derivative in the building industry, converted rice husk into rice husk ask before using it in the formation of concrete cubes. Onyemachi noted that by converting rice husk into ashes all the organic substances that would other wise create inadequate bonding in the concrete would have been destroyed and rendered inorganic.

George F.B. (1975) revealed that sulphate and acid may be present in clay, bricks, in soil, in ground water and also present in sea-water as a result of industrial processes or from organic matter in the soil. They have the ability of destroy the effectiveness of cement. This can be remedied by using very finely grinded material example rice husk. Aba (1996) revealed that the particle size have influence on the strength and workability of concretes. Also high density, impermeability and well compacted concrete will hinder the operation of the suphates and acids.

Specially manufactured cement can be used to minimize or eradicate the effect of chemicals such as sulphate, acids and chlorides.

Sulphate Resisting Portland Cement. This cement has the same materials as Portland cement but the method of manufacture is different which makes it to have slight chemical differences resulting in better performance in resisting attack from sulphate. Ordinary Portland cement is not resistant to 
acid. It is mainly used in concrete works or concrete elements exposed to sea-water or concretes below ground level where sulphate abounds.

Water-Repellent Portland Cement. It is ordinary Portland cement with some quantity of water repellent additions. It makes it difficult for water to penetrate the concrete and weaken it. Hydrophobic Portland cement is also specially treated to produce water repellent film that prevents the cement from absorbing moisture during storage.

High Alumina Cement: It is a Portland cement made by fusing together of lime stone and bauxite or aluminum ore. It develops strength so rapidly that at the age of 24 hours a strength of $55 \mathrm{~N} / \mathrm{mm} 2$ is developed. It resists the attacks of sulphates and acids.

Supersulphated Cement: It is a mixture of blastfurnace slag, ordinary Portland cement clinker and a larger amount of gypsum or calcium (sulphate). This cement is often used where concrete is exposed to attack by weak acids and sulphates.

\section{REFERENCES}

Aba J.O (1996) Strength of concrete elements in building. Unpublished manuscript University of Jos.

Amobi (2005) Maintenace of building and related infrastructure. El-Bez and Co Publishers Owerri.

George F.B (1975) Cement and Concrete Association. Wexham Springs Slough S13 6PL.

Maslehedean. M. (1990) Chemical effects on concrete elements. American Concrete Abstract

Monosi. S. Alvera, I, Collepard in, (1989) Chemical attack of calcium chloride on Portland cement paste. Americana concrete Abstract 18 p 120.

Olabiron E.O (1998) Test result of rice husk slabs A B C D with rice husk treated in Opara P.N (1998) PhD desertation. Nigerian Road and building research institute NBRRI. Lagos.

Okorie J.U (1994) Agricultural Science for senor Secondary Schools, Onitsha Summer Educational publishers. LTD.

Onyemachi, G.A (1994) utility of rice husk and its derivatives in building industry. Unpublished Bsc. Thesis. University of Nigeria Nsukka. 